\title{
Soil development on dolerite and its implications for landscape history in southeastern Tasmania
}

Rafael Osok and Richard Doyle ${ }^{\mathrm{a}}$

School of Agricultural Science, University of Tasmania, PO Box 252-54, Hobart, TAS 7001

\begin{abstract}
Soil genesis has been examined using field description, particle size distributions, chemical properties, mineralogy and elemental distributions of five soil profiles developed on dolerite on Mt Nelson and Tolmans Hill near Hobart in Tasmania. The soils form a sequence ranging from a Black Vertosol (P8) to four texture contrast soils namely a Eutrophic Brown Chromosol (P5), two Mottled-Subnatric Grey Sodosols (MN8 and P4), and a Mottled Mesonatric Grey Sodosol (P7). The soil stratigraphic and pedological relationships of these soils have been investigated to help understand their distribution and improve understanding of soil formation history. The knowledge of the soil stratigraphy and weathering features aid in the determination of the broader landscape history. The field observations show the local dolerite has been subjected to both deep weathering and severe erosional periods. Pockets of deeply weathered dolerite occur adjacent to thin $\mathrm{A} / \mathrm{C}$ soils or hard outcropping rock. Deeper colluvial soil materials occur on lower slopes. The presence of protruding dolerite columns now buried by transported clayey slope-wash materials indicates partial landscape stripping followed by re-burial. The presence of buried stone-lines separating the upper profile from the clayey subsoils supports the idea of a second major erosional-depositional cycle.
\end{abstract}

A pronounced variation between the A and B horizons particle-size distribution, mineralogy and elemental distribution supports the conclusion that the modern soils are composed of several sedimentary layers which cap a variable thickness of in situ weathered dolerite (termed "mealy material") above fresh dolerite. Bedrock jointing, veins and rock fabric extend upward from the bedrock into the mealy material but are truncated abruptly at the contact with the clayey subsoil. Soil forming processes have operated to modify soil colours and mottling, soil structure and cation chemistry. These findings have important implications for landscape history, slope processes and the improved understanding of the distribution of dolerite derived soils in Tasmania.

\footnotetext{
${ }^{a}$ Corresponding author. Tel.: +61-3-6226 2622; fax: +61-3-6226 2642

E-mail address: Richard.Doyle@utas.edu.au
} 


\section{Introduction}

Dolerite-derived soils cover about one third of Tasmania and are found under a wide range of topographic, climatic and vegetative conditions. Five soils formed on dolerite at Mt Nelson and Tolmans hill were selected for further investigation. The key types of soil formed on dolerite were first outlined by Nicolls (1958) as Black clay soils on dolerite (Bld), Brown soils on dolerite (Bd), Podzolic soils on dolerite (Pd), Krasnozems on dolerite $(\mathrm{Kd})$ and Yellow-brown soils on dolerite solifluction deposits (Ybs). Tiller (1962) examined the mineralogy and redistribution of some trace elements during weathering and formation of dolerite derived soils. Neither of these studies determined the stratigraphy of these soils but Loveday (1957) suggested the high quartz content of the fine sand fraction from topsoils of dolerite derived soils north-east of Hobart may be aeolian. Our field observations have shown that many of the soils on dolerite in the $\mathrm{Mt}$ Nelson and Tolmans Hill areas of Hobart are characterised by a surface layer of powdery, stone-free, loamy fine sand overlying fine sandy loam A2 or A3 horizon which is abruptly separated by a stone-line from the gritty clay subsoils (B21, B22). The clayey B2 horizons abruptly cap a compact, gritty weathered dolerite C horizon, termed "mealy material" that appears in-situ as it exhibits rock fabric and veins extend upward from the bedrock into it. The stone-lines that separate the upper lighter textured profile from the clayey lower horizons may contain abundant ferruginous nodules particularly at impeded or poorly drained sites. As data on the petrology and geochemical variation of dolerite are limited fresh samples from both Mt Nelson and Tolmans Hill were analysed. The presence of stratified profiles based on field evidence is further supported by detailed mineralogical, chemical and particle-size analysis.

The aim of this work has been to demonstrate the complex erosion, depositional and soil development history on dolerite hill slopes in Southeastern Tasmania. The findings have implications for the understanding of soil profiles and their development and hence their landscape distribution.

\section{Study area}

The five soil profiles studied are located at Mt Nelson and Tolmans Hill, Hobart, Tasmania (Figure 1). Mt Nelson and Tolmans Hill were selected because they have extensive areas of dolerite with a wide range of soils developed across a range of 
topographic settings. The study area is generally hilly and elevation ranges $50-350 \mathrm{~m}$ above sea level. Topography consists mainly of dolerite plateaux forming hilltops with steep side-slopes and narrow incised valleys. The study area is located within the dry zone of Tasmania $(<800 \mathrm{~mm} / \mathrm{yr})$. The annual rainfall is $619 \mathrm{~mm} / \mathrm{yr}$ at Ellerslie $\mathrm{Rd}$ Station Hobart City (5km NE of Mt Nelson). The mean rainfall ranges between $41 \mathrm{~mm}$ (Feb) and $63 \mathrm{~mm}(\mathrm{Oct})$. In January and February pan evaporation is three times rainfall and only in June and July does rainfall greatly exceeds pan evaporation thus leaching is very limited. The vegetation type is dry sclerophyll forest and woodland dominated by Eucalyptus globulus (blue gum), E. ovata (swamp gum) and E. pulchella (white peppermint) with acacia and others herbaceous types as the second strata. Themeda australis and Poa australis grasses are the most common ground cover.

\section{Methods}

\subsection{Field sampling}

Five representative soil profiles were selected from key geomorphic locations and described according to McDonald et al. (1998). A total of 43 bulk samples including coarse fragment and ferruginous nodules were collected. Dolerite bedrock was sampled from both Mt Nelson and Tolmans Hill area. Seepage water was collected from the abrupt A2 - B21 boundary of profiles MN8 and P7 in the late Spring (2001).

\subsection{Laboratory analysis}

All bulk samples were air-dried and $2 \mathrm{~mm}$ sieved for particle size analysis, chemical, mineralogy and elemental analysis. Coarse fragments and ferruginous nodules were removed by dry sieving at $2 \mathrm{~mm}$, washed and dried. Particle size analysis was carried out according to the plummet balance method of McIntyre and Loveday (1974). The sand fraction was then separated by sedimentation, air-dried and sieved through $1 \mathrm{~mm}$, $0.5 \mathrm{~mm}, 0.25 \mathrm{~mm}, 0.125 \mathrm{~mm}, 0.09 \mathrm{~mm}, 0.063 \mathrm{~mm}$ and $0.045 \mathrm{~mm}$ mesh Endecott sieves. Chemical characteristics included $\mathrm{pH}$ and electrical conductivity in 1:5 soil to water ratio, organic carbon (Walkley-Black method), exchangeable cations and aluminium by ammonium chloride extraction were measured according to Rayment and Higginson (1992). Phosphate in water was determined by Ion Chromatography APHA method 4110C. Total Al, Fe, Ca, Mg, K and $\mathrm{Na}$ in water were analysed by APHA method 3030/3120. Major elements in the whole soil samples ( $\mathrm{Si}, \mathrm{Ti}, \mathrm{Al}, \mathrm{Fe}, \mathrm{Mn}, \mathrm{Mg}, \mathrm{Ca}, \mathrm{Na}$, $\mathrm{K}$ and P) were determined using a Philips PW 1480 X-Ray Spectrometer using lithium 
borate fusion discs. While trace elements ( $\mathrm{Zr}, \mathrm{V}, \mathrm{Sr}, \mathrm{Ga}, \mathrm{Cu}, \mathrm{Zn}, \mathrm{Ni}, \mathrm{Co}$ and $\mathrm{Mo}$ ) were determined using pressed powder pellet (only Zr presented here). The mineralogy of the whole soil samples $(<2 \mathrm{~mm})$, rock samples, and $63 \mu \mathrm{m}$ and $500 \mu \mathrm{m}$ sand samples were determined using randomly oriented samples an automated Philips X-ray Diffractometer with $\mathrm{Cu}$ radiation and a graphite monochromator. Semi-quantitative analysis using peak height was used to calculate mineral abundances.

\section{Results}

\subsection{Characteristics of parent rock}

On Mt Nelson and Tolmans Hill the dolerite is dominantly medium-grained (1-5mm) with coarse columnar jointing. Finer medium-grained $(1-3 \mathrm{~mm})$ dolerite sometimes occurs with an associated finer jointing pattern. In places, strongly weathered mediumgrained dolerite with a spheroidal weathering pattern produces a thick zone of yellowish brown, gritty material. This weathered material extends down joints with a distinct flaky fabric (Plate 1). Coarser medium-grained dolerite $(3-5 \mathrm{~mm})$, ranging from slightly to strongly weathered, forms more reddish brown iron stained, coarse gritty mealy material. In places calcified tree roots have precipitated in the weathering mealy material along joint planes. The jointing density affects both deep drainage and weathering while the grain-size affects the weathering rate, weathering pattern and soil colour (Leaman, 2002). Table 2 shows that the mineralogy of the dolerite on both Mt Nelson and Tolmans Hill consists mainly of plagioclase, clinopyroxene, quartz, kaolinite, smectite, ilmenite, amphibole and K-feldspar. The minerals plagioclase, clinopyroxene, amphibole and K-feldspar are quite consistent between the sites. The medium-grained dolerite was slightly coarser on Mt. Nelson and it shows lower amounts of quartz and higher amounts of the clay minerals kaolinite (10\%) and smectite $(5 \%)$. This suggests it may be more weathered. The slightly finer medium-grained dolerite from Tolmans Hill has slightly more ilmenite and quartz and is lower in both the clay minerals. Table 3 shows that there are only minor differences in elemental contents between the two sites. Mt Nelson has higher $\mathrm{MgO}, \mathrm{CaO}$ and $\mathrm{Al}_{2} \mathrm{O}_{3}$ reflecting the clay minerals present. Tolmans Hill is higher in $\mathrm{SiO}_{2}$ reflecting the higher quartz levels and lower levels of clay minerals. Zirconium is a little higher in Tolmans Hill. The main conclusion drawn for the XRD and XRF data is that the chemistry and mineralogy of dolerite on both sites is very similar and that it has quite high $\mathrm{SiO}_{2}$ level, and is high in $\mathrm{Al}_{2} \mathrm{O}_{3}, \mathrm{CaO}$ and $\mathrm{Fe}_{2} \mathrm{O}_{3}$. Both dolerites have moderate amounts of sodium. 


\subsection{Site characteristics and soil morphology}

The five selected profiles (Figure 1) were classified according to Isbell (1996) and they represented three important soil orders; Sodosol, Chromosol and Vertosol. Summary of the profile descriptions (Table 1) are according to Field Handbook (McDonald, et al., 1998). Profile P5 (Eutrophic Brown Chromosol) is well drained and is on a moderately steep middle slope (26\%) with a NE aspect. Regular dolerite outcrops occur on these slopes and they act as a source of stones and boulders for both soils and the land surface immediately down slope. Profile MN8 (Mottled-Subnatric Grey Sodosol) is moderately well drained and is on shoulder of the NE slope at Mt Nelson. The site is on a gentle slope $(8 \%)$ section that gives way to a steeper valley slope and an incised gully. A few dolerite outcrops are found on this slope and they become very common on the steeper lower slopes. They are the source of coarse fragments for soils forming immediately down slope. Profile P4 (Mottled-Subnatric Grey Sodosol, Plate3) is located on the lower part of a SW facing mid-slope of Mt. Nelson with imperfectly drained. The slope angle is $26 \%$ and rock outcrops are common along the slope. Profile P7 (MottledMesonatric Grey Sodosol, Plate 2) is poorly drained and forms in a drainage depression descending the Tolmans hill crest. The site has a 10\% slope and NE aspect. Dolerite outcrops are common surrounding the site and they provide sources for surface and profile stones. Profile P8 (Black Vertosol) is a dark cracking clay soil that occupies the lower part of a NE facing slope (16\%) descending the Mt Nelson plateaux-crest. It extends up slope until a marked break in slope at $280 \mathrm{~m}$ where slope angle decreases and texture contrast soils develop. Dolerite outcrops are common and are the source of scattered surface and stone-line coarse fragments.

Profiles P5, MN8, P4 and P7 are all texture-contrast profiles or duplex in the scheme of Northcote (1960). They have fine sandy surface horizon capping gritty clay B horizons and the presence of a stone-line composed of dolerite fragments and ferruginous nodules marks the abrupt topsoil-subsoil boundary. Large pebbles $(20-60 \mathrm{~mm})$ with sub-rounded to angular shapes are dominant in P5 and MN8 indicating poor sorting and short transport distances. The weak weathering of the fragments (weathering rinds $<2$ $\mathrm{mm}$ ) indicates a source of fresh bedrock exposure up slope. In the lower slope and wetter sites, P4 and P7, the dolerite fragments consist of more rounded large pebbles (20-60 mm) and few cobbles $(60-200 \mathrm{~mm})$. The abundance of ferruginous nodules also increases in the $\mathrm{A} 2$ and $\mathrm{B} 21$ horizons of $\mathrm{P} 4$ and $\mathrm{P} 7$. This is associated with more severe 
and more regular redox phases in these profiles (Rhoton et al., 1993). Gleyic colouring, mottling and massive structure are prominent features (P4 and P7). Large pebbles and cobbles that form stone-lines cannot have been sourced from the in situ bedrock beneath as the stone-line and fresh rock are separated by highly weathered mealy dolerite or the $\mathrm{C}$ horizon. The four texture-contrast profiles also exhibit a distinctive grittiness in the clayey B2 and B3 horizons. The grittiness increases with depth due to an increased content of the lithic fragments that appear to have been derived from disaggregation and transport of the formerly exposed mealy layers up slope. The B2 horizons tend to be blocky structured when dry but appear massive when wet which induces lateral moisture seepage along their upper boundary, a marked textural hiatus. Profile P5 has a high chroma and value in the B2 horizons indicates better drainage, while the presence of ochreous mottling in the B21 horizon of the MN8, P4 and P7 indicates Winter-Spring wetness. Profile P8 exhibits weaker differentiation of soil horizons probably due to shrinking-swelling properties as indicated by common medium to coarse cracks $(5-20$ $\mathrm{mm}$ ) above the B2 horizon. Profile P8 has a fine sandy A1 horizon and then grades to clay loam and heavy clay with depth. Profile P8 has a more diffuse stone-line, which is discontinuous along the boundary of the A12 horizon and A3 horizon. The more gradational nature of this soil and the less distinct stone-line is probably a reflection of the pedo-turbation. In P5 and P7, a B3 horizon occurs below the B22 horizons and contains more gritty lithic fragments, however it does not have the distinctive rock fabric or vein features as found in the $\mathrm{C}$ horizon and are considered transported materials. The subsoils of all profiles overlie weathering in situ dolerite termed "mealy" material or C horizon (Nicolls, 1958). In P8, the mealy layer has been divided into an upper more clayey $\mathrm{C} 1$ and less clayey $\mathrm{C} 2$ horizons. The $\mathrm{C}$ horizon appears to be formed from weathering in place due to the presence of bedrock weathering features such as veins and rock fabric that extend upper-ward from the fresh rock into the mealy layer.

\subsection{Key chemical characteristics of soils}

Basic soil chemical parameters were determined to measure the influence of pedogenic processes on the profile (Table 4). Organic matter accumulation, cation leaching and strong $\mathrm{pH}$ depth trends appear as the key pedogenic influences on the soil materials. Organic carbon is high in the surface horizon of all profiles and decreases rapidly with depth. The soil $\mathrm{pH}$ is slightly acid at the surface horizon of all profiles, and tends to increases with depth. The slight decrease of $\mathrm{pH}$ in the $\mathrm{A} 2(\mathrm{MN} 8, \mathrm{P} 4, \mathrm{P} 7)$ and $\mathrm{A} 3$ 
horizons (P5) reflects the leaching of $\mathrm{Ca}^{2+}$ by lateral seepage (Table 5). Profile P8 shows the most dramatic increase in $\mathrm{pH}$ with depth, from slightly acid in the A11 and A12 surface to slightly alkaline in the B2 and moderately alkaline in the $\mathrm{C}$ horizon. The increase of $\mathrm{pH}$ in the lower horizons of the all profiles is linked to the dominance of $\mathrm{Ca}^{2+}$ and $\mathrm{Mg}^{2+}$ ions on exchange complex in the B2, B3 and C horizons. Exchangeable $\mathrm{Ca}^{2+}$ and $\mathrm{Mg}^{2+}$ show an abrupt change in the all profiles. They dominate the $\mathrm{B} 21$ and B22 horizons and tend to increase with depth. Profile P8 has the highest levels of exchangeable $\mathrm{Ca}^{2+}$ and $\mathrm{Mg}^{2+}$ throughout the profile. The high ECEC in the $\mathrm{B}$ and $\mathrm{C}$ horizons of all profiles are more related to higher clay content, and the presence of smectite. The poorer drained profiles ( $\mathrm{P} 4, \mathrm{P} 7)$ have higher sodicity in the $\mathrm{B}$ and $\mathrm{C}$ horizons. Sodicity increases with site wetness and is quite dramatic in the wetter subsoils. Sodium has been shown to be the major ion in rainwater in eastern Tasmania (Jackson, 2000). Thus $\mathrm{Na}$ is continually supplied and leached through the landscape and can accumulate in the lower lying profiles. Profile P7 has the highest subsoil electrical conductivity values and it is classified as slightly saline $(0.26 \mathrm{dS} / \mathrm{m})$.

The chemical composition of seepage water sampled at the A2-B21 boundary of MN8 and P7 highlights the movement of large amounts of $\mathrm{Na}, \mathrm{Fe}$ and $\mathrm{Al}$ is critical for both the formation of ferruginous nodules and the development of sodicity (Table 5). Calcium and $\mathrm{Na}$ dominate the lateral drainage water from MN8. The data highlight the movement of the exchangeable cations in particular $\mathrm{Ca}$ and $\mathrm{Na}$ in both soils (MN8 and $\mathrm{P} 7)$, and the mobility of $\mathrm{Fe}$ and $\mathrm{Al}$ in the wetter site (P7).

\subsection{Particle size distribution}

The results of particle size analysis (Table 6) show a marked difference in the size fractions with depth of all profiles, in particular the changes from the A horizons to the $\mathrm{B} 2$ horizons, and from the B22/B3 horizons to the $\mathrm{C}$ horizon. The better-drained profiles (P5, MN8) express this most clearly highlighting the three very differently textured materials in the profiles. Silt is also highest in the surface of all profiles. Clay contents abruptly increase in the B21 horizons of all soils and then generally decrease with depth in B22 and B3 horizons. Clay contents then drop abruptly in the C horizon. Detailed analysis of sand fractions were undertaken to clarify the field textures which indicated that although both the topsoils and the mealy substrate were both sandy they were quite different sand fractions. There are significant changes in sand-size distributions with depth in all profiles. All surface horizons are dominated by fine $(<125$ $\mu \mathrm{m})$ to very fine $(45-20 \mu \mathrm{m})$ sand while the mealy substrate is dominated by the coarser 
sand fractions. There is an abrupt increase in the coarser sand fractions $(>250 \mu \mathrm{m})$ of all the B2 horizons, except for profile P7 that occurs in a drainage depression. The coarser sand in the lower horizons is composed almost entirely of dolerite lithic fragments and ferruginous nodules. The high fine sand fraction in all the surface horizons (A1, A2 and A3) concurs with the high silt contents and supports the notion of exotic aeolian provenance (loess). A distinct clay bulge occurs in all subsoils commonly the B21 or A3 horizon. The source of the clay is likely to be from slope wash derived from subaerially exposed mealy layers up slope, as it is bimodal, being both gritty and clayey. The mealy layer ( $\mathrm{C}$ horizons) at the base of all soils is considered to be in-situ weathered material and contain moderate amounts of both clay and coarse sand. Silt distribution shows a distinct maximum in the surface horizons (A2, A3) of all profiles.

\subsection{Mineralogy of soils}

The distribution of soil minerals in all profiles (Table 7) varies abruptly with depth thus adding support to the field stratigraphy identified. Quartz is the most abundant mineral in the all A horizons of all profiles. Quartz is greater that $80 \%$ in the A1 horizon of P7 and is $60-80 \%$ in the surface horizon of all other soils despite fresh dolerite containing only 20\% quartz (Table 2). Quartz remains high (60-80\%) in the A2 and A3 (P5) except P8 where it is (40-60\%). In both better-drained soils (P5, MN8), quartz drops abruptly to $25-40 \%$ in the $\mathrm{B} 21$ and to $15-25 \%$ in the $\mathrm{B} 22$ horizons. In the wetter soils (P4, P7), quartz remains high in the B21 and B22 suggesting more active winnowing of clays by slope wash. In these soils fine sand was observed lining shrinkage cracks in the B2 horizons, having been washed there from the sandy A2 horizons or the upper horizons. The in situ weathered mealy layer (C horizon) contains only $10-15 \%$ quartz, which is less than the fresh dolerite (20-25\%). This suggests that differential weathering in place does not concentrate quartz, by contrast some quartz may be weathered to clays or lost by leaching. This lost quartz probably reflects the prolonged weathering of the in situ mealy layer. The marked difference in quartz distribution indicates at a partly exotic source of quartz. While localised winnowing by slope wash may provide an efficient supply, aeolian accession from adjacent siliceous parent materials is compatible with the high fine sand and silt fractions common to the upper part all profiles.

The $\mathrm{C}$ horizon (mealy layer) of all soils is dominated by plagioclase, quartz and clinopyroxene, and smectite and halloysite, the same minerals that dominate fresh dolerite. Plagioclase and clinopyroxene appear to have suffered the greatest losses due 
to weathering and result in the formation of smectite and halloysite. The absence of clinopyroxene in the P4 and P7 indicates it may also have been altered to amphibole by earlier hydrothermal weathering (Sutherland, 1997; Leaman, 2002). Plagioclase content progressively increases with depth highlighting its low resistance to both weathering and subaerial transport. On higher landscape positions or in the better-drained profiles (P5, MN8) smectite shows a sharp increase from the surface to the B2 horizons, while on the lower landscape position the wetter sites (P4, P7) and P8 smectite content is more constant with depth. In the B2 horizons, halloysite dominates the well-drained soil (P5) and smectite dominates the poorer drained profiles (P4, P7, and P8). Ilmenite, amphibole and laumonite show no significant changes with depth. Stilbite, an alteration product associated with hydrothermal environments and as discussed earlier may indicate ancient hydrothermal weathering of dolerite in some parts of the landscape.

X-ray diffraction analysis of the $500 \mu \mathrm{m}$ and $63 \mu \mathrm{m}$ sand fractions supports the idea of sedimentary layering in the solum (Table 8). Quartz is highly concentrated in both coarse and fine sand fraction of the $\mathrm{A}$ and $\mathrm{B}$ horizons, while the $\mathrm{C}$ horizon is dominated by plagioclase. The highest proportion of quartz is found in the $63 \mu \mathrm{m}$ sand fraction of the A1 and A2, typical of loess (Margolis and Krinsley, 1971, Mokma et al, 1972). The sharp break in the distribution of $63 \mu \mathrm{m}$ quartz between the B22 (50-60\%) and C horizons (10-15\%) supports the notion of the transported nature of the subsoil. Kfeldspar occurs in greatest proportion in the A1 and A2 of coarse fraction $(500 \mu \mathrm{m})$ and in the B21 and B22 and is probably derived by slope-wash from exposed mealy materials upslope. Profile MN8 and P7 support this as no K-feldspar was detected in the mealy layer but $\mathrm{K}$-feldspar is present at $5-10 \%$ levels in the surface. The presence of both plagioclase and smectite in the coarse and fine sand fraction of the $\mathrm{C}$ horizon in MN8 indicates that the smectite maybe forming inside the plagioclase crystals on weathering as indicated by Taboada and Garcia (1999). The presence of 5-10\% hematite in the $500 \mu \mathrm{m}$ sand fraction of A1 and A2 (MN8) is associated with fine ferruginous nodules.

\subsection{Distribution of selected elements in the profiles}

Examination of the data in Table 9 should be made with reference to Table 3. Silica, $\mathrm{TiO}_{2}$ and $\mathrm{Zr}$ are all significantly higher in the upper horizons of all profiles (Table 9). A dramatic decrease in $\mathrm{SiO}_{2}$ and $\mathrm{TiO}_{2}$ occurs in the $\mathrm{B} 21$ of the $\mathrm{P} 5$ and $\mathrm{MN} 8$, although the values are still higher than fresh dolerite. Despite the chemical weathering evident in 
the $\mathrm{C}$ horizon, they contain similar amounts of $\mathrm{SiO}_{2}, \mathrm{Zr}$ and $\mathrm{TiO}_{2}$ as dolerite bedrock. This supports the idea that weathering alone has not lead to the relative concentration of these elements in the upper layers, some degree of sedimentary winnowing or exotic providence is required. Potassium is higher in the upper horizons of all profiles and is most affected by the amount of K-feldspar present, which is relatively resistant to weathering (Goldich, 1938). K-feldspar is elevated in the surface horizon of all texturecontrast soils and is considered detrital. The lower $\mathrm{SiO}_{2}$ level in the $\mathrm{B} 21$ of $\mathrm{P} 7$ reflects the higher content of ferruginous nodules and hence iron oxide content at this wet site. Both $\mathrm{Al}_{2} \mathrm{O}_{3}$ and $\mathrm{Fe}_{2} \mathrm{O}_{3}$ follow similar trends with depth. They have the second and third highest concentration in all profiles. They are low in the upper sandy surface horizons and sharply increased in the B21 and B22 horizons. The rapid increase in A1 relates to the increase in clay content while the increase in Fe relates to the presence of ferruginous nodules in both $\mathrm{B} 21$ and $\mathrm{A} 2$ horizons. In poor-drained profile $(\mathrm{P} 7)$, the marked decrease in $\mathrm{Al}_{2} \mathrm{O}_{3}$ and $\mathrm{Fe}_{2} \mathrm{O}_{3}$ in the $\mathrm{B} 22$ corresponds with a peak in $\mathrm{SiO}_{2}$. The content of both $\mathrm{Al}$ and $\mathrm{Fe}$ oxides in the lower horizons (B3, $\mathrm{BC}$ and $\mathrm{C}$ horizons) is similar to that of fresh dolerite and suggests little loss of released $\mathrm{Al}$ and $\mathrm{Fe}$ on weathering. These elements are thus retained in clay minerals and Fe oxides in the weathered fraction and not lost through leaching. This contrast with the upper sandy horizons where transport and winnowing of clays has lead to much lower amounts of both $\mathrm{Al}$ and $\mathrm{Fe}$ oxides. More mobile elements such as $\mathrm{Ca}, \mathrm{Mg}$, and $\mathrm{Na}$ exhibit strong relative losses from all the upper layers where sub-aerial weathering and transport have depleted these elements due to loss of plagioclase feldspars and smectite. A marked increase in the content of $\mathrm{Mg}, \mathrm{Ca}$ and $\mathrm{Na}$ occurs between the $\mathrm{A} 2$ or $\mathrm{A} 3$ and the $\mathrm{B} 21$ horizon in the two better-drained soils (P5, MN8). Both $\mathrm{Ca}$ and $\mathrm{Mg}$ are more depleted, by leaching, from the wetter sites, especially P7 and these elements accumulate in the lower profiles of the drier sites of P8 and P5. Manganese is more mobile under anaerobic conditions (McKenzie, 1977) and it is thus not surprising that Mn is much higher in the better-drained profiles (P5, P8) than in the poorly drained sites (P4, P7). Zirconium is highest in the A1, A2 and A3 of all profiles reflecting its presence in the weathering-resistant, detrital mineral zircon. This difference also supports the assumption of a discontinuity of soil material between the upper profiles (A1 and A2, A3) and the subsoils. Zirconium then decreases with depth in the subsoils reflecting their origin as re-worked mealy material, derived locally from upslope. Zirconium is lowest in the $\mathrm{C}$ horizon despite the dominance of clay minerals indicating strong 
alteration of this horizon. Thus weathering in situ does not appear to increase zirconium content while increased intensity of sub-aerial winnowing and transport does.

\section{Discussion}

Examination of the five soil profiles and analytical data presented indicate that at least four separate soil stratigraphic materials can be identified on soils formed above dolerite. Only the mealy weathered dolerite ( $\mathrm{C}$ horizon) and the bedrock itself appear in-situ. Pedogenic modification has altered the character of some materials such that the soil matrix colours, mottling and ferruginous nodule abundance vary with drainage condition. Organic matter accumulation and lower $\mathrm{pH}$ values in the upper profile further reflect pedological influences. Soil structure is also affected by pedological processes such as exchangeable $\mathrm{Na}^{+}$, organic matter levels and shrinkage on drying. Halloysite appears to be more abundant in the better-drained soils. However, soil texture, stoniness and mineralogy highlight an inherited soil stratigraphy, which greatly impacts on the sequence of soil horizons present. Four key separable materials are identified as follows:

1) A loamy fine sand A1 horizon with relatively free coarse fragments and having a soft powdery structure forms the 4-6 cm deep topsoil. This layer is dominated by quartz and has high amounts of $\mathrm{Zr}, \mathrm{SiO}_{2}$ and $\mathrm{TiO}_{2}$ which typically occur in resistant sand fraction minerals. The layer has high silt and fine sand contents and aeolian influxes are considered highly likely. The A2/A3 horizon below is typically fine sandy. In wetter sites (P4, P7) this material develops a gleyic character (A2 type horizon; McDonald et al 1998), while at drier (P5, P8), sites it forms a lower topsoil (A3 type of horizon).

2) A dolerite stone-line separates the A2 from the clayey B21 horizon lying below. This sedimentary lag is partly incorporated into the A2 above and the B21 below. The stones range in size from $20-200 \mathrm{~mm}$ and vary in shape from sub-rounded to angular. In some soils dolerite of much finer grain size was noted in the stone-lines than the dolerite underlying the profile clearly demonstrating it is sourced from further upslope. Very thin, $<2 \mathrm{~mm}$, weathering rinds suggest the stone lines are a moderately recent feature.

3) Plastic, tough, compact, gritty and/or sandy clay. This clay horizon forms a B21 horizon and the matrix color and mottling are affected by topographic position. In profiles on gentle slopes (MN8) the clay has orange mottles while on steep convex 
slopes (P5) the clay is brown to reddish brown. On lower slopes this clay material is very dark brown to black (P8) while in topographic depressions (P7) it is quite mottled and grey. At most sites this horizon is underlain by blocky, plastic, gritty sandy clay, which forms a B22 horizon. This clayey B22 material is similar to the B21 above but contains more grit and may have gleyic features if it contacts compact mealy substrate (hydraulic hiatus).

4) "Mealy" material forming an in situ gritty $\mathrm{C}$ horizon. This material and the dolerite rock below are the only parts of the profile in situ. It forms a gritty material composed of weathering dolerite rock and can be seen to grade into the underlying fresher rock by a series of spheroidal weathering clasts and a flaky structured mealy dolerite extending down joints.

The presence and significance of stone-lines in soils has been reported previously by Parizek and Woodruff (1957), Ruhe (1958) and Moeyersons (1989). The wide variation in size and shape of the stones support the notion they are transported or the product of sedimentary processes (Finkl and Churhward, 1976). Ruhe (1958) indicates that the presence of stone-lines in a soil profile indicates that the soils have formed from more than one material. The occurrence of stone-lines on a marked textural hiatus is associated with restricting water movement in several of the studied soils.

Seepage water sampled during the wet Winter-Spring period (2001) indicated that $\mathrm{Na}$, $\mathrm{Ca}$ and $\mathrm{Mg}$ were the major ions moving through the drainage waters of moderately well drained soil (MN8). In addition Fe and Al were mobile in the poor drained soil (P7). The alternating wet and dry conditions also promotes the formation of Fe-nodules at this textural hiatus (Rhoton et al., 1993).

The extremely high quartz contents in the soil above the stone-line of texture-contrast soils (P5, MN8, P4, P7) and above the A3 of Black Vertosol (P8) indicate the detrital nature of the material. The very high amounts of smectite in the $\mathrm{C}$ horizon of all soils indicates that smectite is the key weathering product of dolerite and its formation indicates a low leaching weathering environment. Its formation appears to be due to in situ weathering of plagioclase and pyroxene. The moderate levels of smectite in the B21 and B22 of all profiles and its presence in the A1 and A2 horizons suggests it is resilient to sub-aerial exposure and slope wash. This also indicates a low leaching weathering environment has been a feature of this landscape for some considerable time. 
The high content of quartz in both the coarse and fine sand fraction in the upper profiles and the high K-feldspar in the coarse sand fraction support the notion of sedimentary winnowing and concentration of resistance mineral components. These resistant minerals occur in very low levels in the weathered mealy layer (C horizon).

The evidence of elemental distribution shows that the resistant oxides of silicon, zirconium and titanium are very high and retained in the surface layers above the stoneline, but decrease markedly in the subsoil and drop further still in the mealy material. In the mealy layer most elements show little difference in concentration from that of fresh dolerite bedrock other than a slight loss in Si. The wetter sites (MN8, P4, P7) also show loss of $\mathrm{Ca}$ while the better-drained sites (P5, P8) show loss of both $\mathrm{K}$ and $\mathrm{Na}$ through leaching. This data strongly suggest the mealy layer or $\mathrm{C}$ horizon has weathered in place in a low leaching aerobic environment.

\section{History of soil development}

Outlined below is a proposed soil-landscape history based on the data presented above and field examination of the soil pattern (Figure 2).

\section{Phase 1 - Initial deep weathering of the dolerite}

A period of extended soil formation and deep weathering of the dolerite during which a deep weathering profile developed, remnants of which can be seen protected behind fresh dolerite bars on Mt Nelson and Tolmans Hill. The modern day irregular pattern of deeply weathered zones of dolerite adjacent to fresh rock may indicate fractures in the dolerite were important for the pattern of weathering. The fractures would allow water and possibly hydrothermal activity to localised and accelerate weathering.

\section{Phase 2 - Stripping}

Deep weathering was followed by regional stripping over much of the soil landscape. This left a truncated soil consisting simply of an in situ, gritty, mealy layer above the less weathered dolerite and protected deeper weathered soils behind dolerite bars. Much of this stripping may have occurred during the various glacial phases of the early-mid Pleistocene, accelerated by frost action and slope wash (Colhoun, 2002).

\section{Phase 3 - Slope wash and new soil formation}


Some time following landscape stripping re-working of the exposed mealy materials has provided sediment to generate the gritty and clayey B22 and less gritty B21. These materials were probably exposed for a short period of soil formation and weathering. The presence of floaters within the B2's with only thin weathering rinds indicates the brevity of landscape stability.

\section{Phase 4 - Formation of stone-line}

Following an unknown period of soil weathering a deposit of coarser material has mantled the B21 and B22s forming a distinct stone-line in the landscape. These stones are likely to have been derived from freeze-thaw processes acting on exposed outcrops, associated with the last and coldest part of the last Glaciation (18 Ka BP). Indeed their movement though the landscape is likely to have been accelerated by peri-glacial environments.

\section{Phase 5 - Influx of fine sandy sediments}

The stone-lines have been capped by fine sandier materials dominated by quartz. Given the silty and fine sandy particle-size distribution and very high quartz content it is likely that much of the upper soil is foreign to the local landscape i.e., it is reworked loess. Quartz rich sources abound the broader regional geology (Triassic and Permian sediments; Figure 1) and aeolian deposits are common to all eastern regions of Tasmania (Loveday 1957, Nicolls, 1958a, Sigleo and Colhoun, 1982; McIntosh, 1999 and Colhoun, 2002). Thus the conclusion drawn here is that a good proportion of the upper profile is aeolian derived, though subject to local reworking by slope wash processes and pedo-turbation.

\section{Conclusions}

This study of five selected soils on dolerite suggests that the occurrence of texturecontrast soils and a Black Vertosol are formed in materials related to erosionaldepositional landscape history of the study area. At least four soil materials can be identified and separated using field and laboratory analysis and only the $\mathrm{C}$ horizon (mealy layer) is in-situ. Pedogenesis has affected mottling, bleaching, soil colours, organic matter levels, ferruginous nodule formation, sodicity and soil $\mathrm{pH}$ trends. However, the mineralogy, soil textures and their changes down the profile are largely determined by sedimentary deposited materials. Clay translocation cannot be invoked 
to explain the texture contrast in the profiles, in fact the reverse was noted as in several profiles fine sand was seen to have migrated down shrinkage cracks for the A2 to the B2 horizons. In situ weathering occurs in the mealy layer as indicated by the decrease in quartz, plagioclase and clinopyroxene and the increase in smectite and only minor changes in chemistry. The mealy material ( $\mathrm{C}$ horizon) also exhibits bedrock features such as veins and rock fabric. Very high levels of quartz occur in the A horizons and high levels in the B horizons. Such concentration requires a winnowing sedimentary process given the low amounts of quartz in the dolerite bedrock. The peaks in resistant oxides of silicon, titanium, and zirconium particularly in the A horizons but also the B horizons strongly suggests sedimentary action. The presence of stone-lines between the topsoil and the subsoil layers demonstrates the separation of layers and sedimentary nature of the upper profile. These findings indicate two major erosion-deposition cycles have occurred that have important implications for landscape history, slope processes, weathering and the factors affecting soil occurrence in southeast Tasmania.

\section{Acknowledgements}

We would like to express our thanks to the Australian Agency for International Development (AusAID) for financial support of this study.

\section{References}

Colhoun, E.A., 2002. Peri glacial landforms and deposits of Tasmania. South Africa Journal of Science, 98: 55-63.

Finkl, Jnr, C. W and Churhward, H.M., 1976. Soil stratigraphy in a deeply weathered shield landscape in South-western Australia. Australian Journal of Soil Research, $14,109-120$.

Goldich, S.S., 1938. A study in rock weathering. J. Geology, 46, 17-58

Isbell, R.F., 1996. The Australian soil classification. CSIRO Australia.

Jackson, W.D., 2000. Nutrient stocks in Tasmanian vegetation and approximate losses due to fire. Paper and Proceeding of the Royal Society of Tasmania, 134, 1-18.

Leaman, D.E., 2002. The rock, which makes Tasmania. Leaman Geophysics, Hobart, Tasmania.

Loveday. J., 1957. The soils of the Sorell Carlton- Copping area, Southeast Tasmania with special references to the soil formed on basalt. Soil publication no.48, CSIRO Melbourne. 
McBride, M.B., 1994. Environmental chemistry of soils. Oxford University Press, Inc. Toronto.

McDonald R.C., Isbell R.F., Speight J.G., Walker J. and Hopkins M.S., (1998), Australian soil and land survey - Field handbook. Second edition. Australian Collaborative Land Evaluation Program, CSIRO Land and Water, Canberra.

Margolis and Krinsley. 1971. Submicroscopic frosting on aeolian and subaqueous quartz sand grain. Geological Society of America Bulletin, 82, 3395-3406.

McIntyre, D.S., Loveday, J., 1974. Particle-size analysis. In: Loveday, J. (Eds.). Methods for analysis of irrigated soils. Commonwealth Agriculture Bureau Technology Communication, 54, 88-99.

McKenzie, R.M. 1977. Manganese Oxide and Hydroxides. In: Dixon, J.B., Weed, S.B., Kittrick, J.A., Milford, M.H and White, J.L. (Eds.), Minerals in soil environments. Soil Science Society of America, Madison, Wisconsin, USA, pp. 181-191.

McIntosh, P.D., 1999. Problem soils: Aeolian deposits on dolerite. Forest Practices News, 1,1, 17.

Moeryersons. J., 1989. The concentration of stones into stone-lines, as a result from subsurface movements in fine and loose soils in the tropics. Geo-Eco-Trop., 11, $11-22$.

Mokma, D.L., Syers, J.K. and Jackson, M.L., 1972. Aeolian addition to soils and sediments in the South Pacific area. J. Soil Science, 23, 2, 147-162.

Nicolls, K.D., 1958. Soil formation on dolerite in Tasmania. In: Carey, W., (Eds.) Dolerite - a symposium. Department of Geology, University of Tasmania 1957, pp 204-211.

Nicolls, K.D., 1958a. Aeolian deposits in river valleys in Tasmania. Australian Journal of Science, 21, 50-51.

Northcote, K.N., 1960. 'A Factual Key for the Recognition of Australian Soils'. CSIRO Division of Soils. Report No.4/60. CSIRO, Melbourne.

Parizek, E. J and Woodruff, J.F., 1957. Description and origin of stone layer in soils of the south-eastern states. J. Geology, 65, 24-34.

Rayment, G.E and Higginson, R.E., 1992. Australian Laboratory Handbook of Soil and Water Chemical Methods. Inkata Press, Melbourne. Australia. 
Rhoton, F.E., Bigham, J.M and Schulze, D.G., 1993. Properties of iron-manganese nodules from a sequence of eroded fragipan soils. Soil Science Society of American Journal, 57, 1386-1392.

Ruhe, R.V., 1959. Stone lines in soils. J. Soil Science, 87, 223-231

Sigleo, W.R. and Colhoun, E.A., 1982. Terrestrial dunes, man and the late quaternary environment in southern Tasmania. Paleogeography, Palaeoclimatology, Paleoecology, 39, 87-121.

Sutherland F.L., 1977. Zeolite minerals in the Jurassic dolerites of Tasmania: Their use as possible indicators of burial depth. J. Geological Society of Australia, 24, 3, 171-178.

Taboada, T and Garcia, C., 1999. Smectite formation produced by weathering in a coarse granite saprolite in Galicia (NW Spain). Catena, 35, 281-290.

Tiller, K.G., 1962. Weathering and soil formation on dolerite in Tasmania with particular reference to several trace elements. Australian Journal of Soil Research, 1, 74-90. 


\section{Table 1}

Summary soil profile descriptions according to McDonald, et al. (1998)

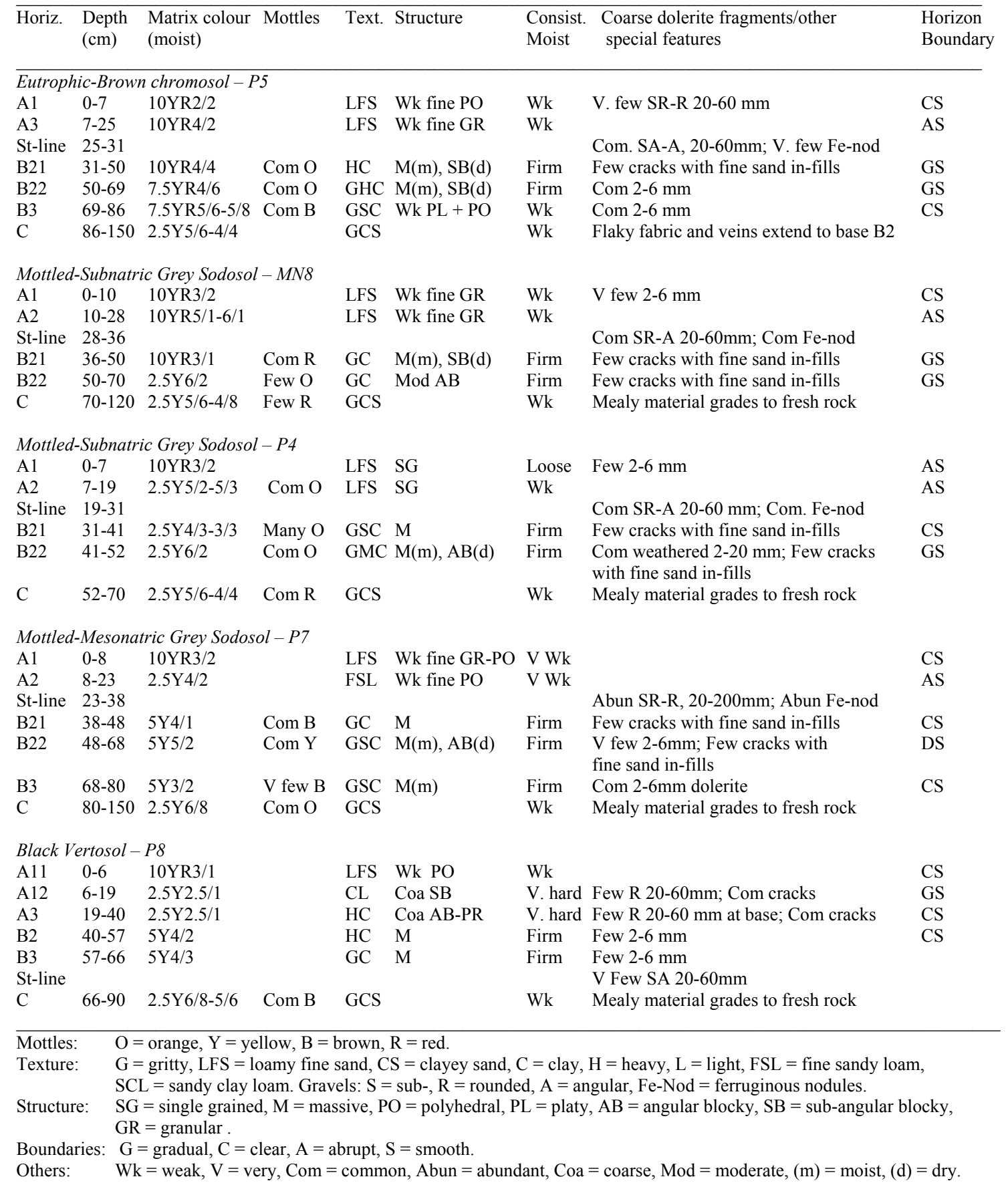


Table 2

X-Ray diffraction analysis of dolerite rock in the Mt Nelson and Tolmans Hill.

\begin{tabular}{lllllllll}
\hline $\begin{array}{l}\text { Sampling Plagioclase } \\
\text { Sites }\end{array}$ & $\begin{array}{l}\text { Clino- } \\
\text { pyroxene }\end{array}$ & Quartz & Kaolinite & $\begin{array}{l}\text { Smectite } \\
(\%)\end{array}$ & Ilmenite & Amphibole & K-Feldspar \\
\hline Mt Nelson & 40 & 20 & 20 & 10 & 5 & 2 & 2 & 2 \\
Tolmans Hill & 40 & 20 & 25 & 2 & 2 & 5 & 2 & 2
\end{tabular}

\section{Table 4}

Chemical composition of water collected from the late Spring Seepage at the A2 - B21 boundary of profile MN8 and P7.

\begin{tabular}{ccc}
\hline Total element $(\mathrm{mg} / \mathrm{L})$ & MN8 & P7 \\
\hline $\mathrm{P}$ & $<0.01$ & $<0.01$ \\
$\mathrm{Al}$ & 0.1 & 5.5 \\
$\mathrm{Fe}$ & 0.2 & 5.2 \\
$\mathrm{Ca}$ & 10.0 & 4.3 \\
$\mathrm{Mg}$ & 5.0 & 3.0 \\
$\mathrm{~K}$ & 1.2 & 1.0 \\
$\mathrm{Na}$ & 12.4 & 24.5 \\
\hline
\end{tabular}


Table 3

Some basic chemical characteristics of soils

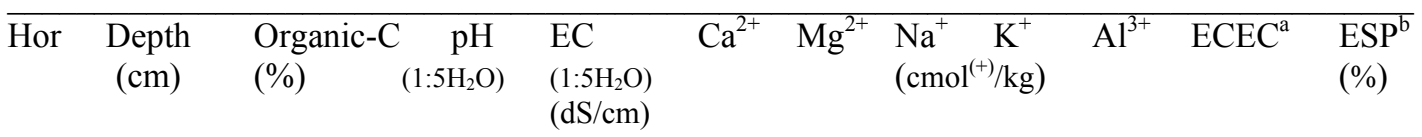

Eutrophic Brown Chromosol-P5

$\begin{array}{llllllllllll}\text { A1 } & 0-7 & 5.6 & 6.2 & 0.04 & 7 & 5 & 0.3 & 0.4 & 0.37 & 13.1 & 2 \\ \text { A3 } & 7-25^{\mathrm{c}} & 3.2 & 6.0 & 0.03 & 4 & 4 & 0.2 & 0.1 & 0.33 & 8.6 & 2 \\ \text { B21 } & 36-50 & 2.7 & 6.5 & 0.05 & 20 & 15 & 1.2 & 0.1 & 0.35 & 36.7 & 3 \\ \text { B22 } & 50-69 & 1.9 & 6.6 & 0.06 & 21 & 17 & 1.6 & 0.2 & 0.48 & 40.3 & 4 \\ \text { B3 } & 69-86 & 1.8 & 6.8 & 0.05 & 20 & 16 & 1.9 & 0.2 & 0.34 & 38.4 & 5 \\ \text { C } & 86-150 & 0.9 & 6.7 & 0.04 & 15 & 9 & 1.0 & 0.1 & 0.34 & 25.4 & 4\end{array}$

Mottled-Subnatric Grey Sodosol-MN8

$\begin{array}{llllllllllll}\text { A1 } & 0-10 & 4.2 & 5.4 & 0.03 & 5 & 4 & 0.4 & 0.4 & 0.87 & 10.7 & 4 \\ \text { A2 } & 10-28^{c} & 3.0 & 5.2 & 0.03 & 2 & 3 & 0.2 & 0.2 & 0.83 & 6.2 & 3 \\ \text { B21 } & 36-50 & 2.3 & 5.8 & 0.04 & 9 & 8 & 1.0 & 0.2 & 0.91 & 19.1 & 6 \\ \text { B22 } & 50-70 & 1.8 & 5.9 & 0.05 & 10 & 12 & 1.2 & 0.1 & 0.89 & 24.2 & 5 \\ \text { C } & 70-120 & 1.6 & 6.3 & 0.06 & 17 & 18 & 2.6 & 0.2 & 0.85 & 38.7 & 7\end{array}$

Mottled-Subnatric Grey Sodosol-P4

$\begin{array}{llllllllllll}\text { A1 } & 0-7 & 2.6 & 5.5 & 0.03 & 3 & 3 & 0.3 & 0.3 & 0.12 & 6.7 & 4 \\ \text { A2 } & 27-19^{c} & 2.2 & 5.4 & 0.03 & 5 & 3 & 0.4 & 0.1 & 0.17 & 8.7 & 3 \\ \text { B21 } & 31-41 & 1.6 & 5.9 & 0.02 & 7 & 8 & 0.7 & 0.4 & 0.24 & 16.3 & 4 \\ \text { B22 } & 41-52 & 1.1 & 6.2 & 0.05 & 10 & 12 & 1.6 & 0.1 & 0.27 & 23.9 & 7 \\ \text { C } & 52-70 & 0.9 & 6.5 & 0.06 & 17 & 24 & 3.5 & 0.1 & 0.26 & 44.9 & 8\end{array}$

Mottled-Mesonatric Grey Sodosol-P7

$\begin{array}{llllllllllll}\text { A1 } & 0-8 & 3.5 & 5.8 & 0.04 & 3 & 4 & 0.4 & 0.6 & 0.48 & 8.8 & 5 \\ \text { A2 } & 8-23^{\mathrm{c}} & 2.8 & 5.7 & 0.03 & 4 & 5 & 0.5 & 0.5 & 0.47 & 10.5 & 5 \\ \mathrm{~B} 21 & 38-48 & 1.9 & 6.0 & 0.18 & 9 & 10 & 2.6 & 0.3 & 0.46 & 21.4 & 12 \\ \mathrm{~B} 22 & 48-67 & 0.4 & 6.6 & 0.25 & 6 & 8 & 2.9 & 0.3 & 0.47 & 17.7 & 16 \\ \text { B3 } & 67-78 & 0.3 & 6.7 & 0.25 & 3 & 14 & 5.4 & 0.7 & 0.47 & 23.6 & 23 \\ \text { C } & 78-150 & 0.2 & 6.2 & 0.26 & 8 & 16 & 7.3 & 0.8 & 0.51 & 32.6 & 23\end{array}$

Black Vertosol - P8

$\begin{array}{llllllllllll}\text { A11 } & 0-6 & 6.6 & 5.6 & 0.09 & 7 & 13 & 0.7 & 0.9 & 0.67 & 22.3 & 2 \\ \text { A12 } & 6-19 & 5.0 & 6.3 & 0.05 & 29 & 18 & 0.8 & 0.6 & 0.60 & 49.0 & 1 \\ \text { A3 } & 19-40 & 3.2 & 6.6 & 0.06 & 31 & 17 & 0.8 & 0.5 & 0.66 & 49.9 & 2 \\ \text { B2 } & 40-57 & 1.6 & 7.5 & 0.04 & 33 & 22 & 1.0 & 0.4 & 0.80 & 57.2 & 2 \\ \text { C1 } & 57-66 & 1.4 & 7.6 & 0.05 & 36 & 22 & 1.3 & 0.3 & 0.70 & 60.3 & 2 \\ \text { C2 } & 66-90 & 0.7 & 7.8 & 0.07 & 31 & 14 & 1.4 & 0.2 & 0.68 & 47.3 & 3\end{array}$

${ }^{a}$ ECEC is calculated as the sum of exchangeable bases and aluminium

$\mathrm{b}_{\%}$ ESP is calculated by exchangeable sodium percentage/sum of bases

${ }^{\mathrm{c}}$ The discontinuous depth interval between the A2 and B21 indicates the thick of stone-line. 
Table 6 XRD mineralogy of whole soils (wt \%)

\begin{tabular}{|c|c|c|c|c|c|c|c|}
\hline Hor $(\mathrm{cm}) \quad 80 \%$ & $60-80 \%$ & $40-60 \%$ & $25-40 \%$ & $15-25 \%$ & $10-15 \%$ & $5-10 \%$ & $<5 \%$ \\
\hline \multicolumn{8}{|c|}{ Eutrophic-Brown chromosol-P5 } \\
\hline $\mathrm{A} 1(0-7)$ & Quartz & & & & Plagioclase & K-feldspar & $\begin{array}{l}\text { Smectite, Laumonite, ilmenite } \\
\text { Amphibole }\end{array}$ \\
\hline$A 3(7-25)^{\mathrm{a}}$ & Quartz & & & & Plagioclase & $\begin{array}{l}\text { K-feldspar, } \\
\text { Smectite }\end{array}$ & $\begin{array}{l}\text { Halloysite, amphibole, } \\
\text { Ilmenite }\end{array}$ \\
\hline B21(36-50) & & & $\begin{array}{l}\text { Halloysite, } \\
\text { Quartz }\end{array}$ & Smectite & Plagioclase & & $\begin{array}{l}\text { K-feldspar, amphibole, } \\
\text { Ilmenite, hematite }\end{array}$ \\
\hline B22 (50-69) & & & $\begin{array}{l}\text { Halloysite, } \\
\text { Smectite }\end{array}$ & Quartz & Plagioclase & & $\begin{array}{l}\text { K-feldspar, amphibole, } \\
\text { Ilmenite }\end{array}$ \\
\hline B3(69-86) & & & $\begin{array}{l}\text { Smectite, } \\
\text { Halloysite }\end{array}$ & Plagioclase & $\begin{array}{l}\text { Quartz, } \\
\text { Clinopyroxe }\end{array}$ & & $\begin{array}{l}\text { K-feldspar, amphibole, } \\
\text { Ilmenite }\end{array}$ \\
\hline$C(86-150)$ & & & Halloysite & $\begin{array}{l}\text { Smectite, } \\
\text { Plagioclase }\end{array}$ & $\begin{array}{l}\text { Clinopyroxe } \\
\text { Quartz }\end{array}$ & ne, & $\begin{array}{l}\text { K-feldspar, amphibole, } \\
\text { Ilmenite }\end{array}$ \\
\hline \multicolumn{8}{|c|}{ Mottled-Subnatric Grey Sodosol-MN8 } \\
\hline $\mathrm{A} 1(0-10)$ & Quartz & & & & & $\begin{array}{l}\text { Smectite, } \\
\text { K-feldspar }\end{array}$ & $\begin{array}{l}\text { Plagioclase, Halloysite, clino- } \\
\text { pyroxene, ilmenite }\end{array}$ \\
\hline $\mathrm{A} 2(10-28)^{\mathrm{a}}$ & Quartz & & & & & Smectite & $\begin{array}{l}\text { Halloysite, clinopyroxene, } \\
\text { Ilmenite }\end{array}$ \\
\hline B21(36-50) & & Smectite & Quartz & & $\begin{array}{l}\text { Halloysite, } \\
\text { Plagioclase }\end{array}$ & & $\begin{array}{l}\text { Clinopyroxene, ilmenite, K- } \\
\text { feldspar, stilbite, amphibole, } \\
\text { Mica }\end{array}$ \\
\hline $\mathrm{B} 22(50-70)$ & & Smectite & & Quartz & Plagioclase & Halloysite & Clinopyroxene, stilbite \\
\hline$C(70-120)$ & & Smectite & & Plagioclase & $\begin{array}{l}\text { Quartz } \\
\text { Halloysite }\end{array}$ & $\begin{array}{l}\text { Clino- } \\
\text { pyroxene }\end{array}$ & Stilbite, clinopyroxene \\
\hline \multicolumn{8}{|c|}{ Mottled-Subnatric Grey Sodosol - P4 } \\
\hline $\mathrm{A} 1(0-7)$ & Quartz & & & & & $\begin{array}{l}\text { Plagioclase, } \\
\text { K-feldspar }\end{array}$ & $\begin{array}{l}\text { Smectite, ilmenite, amphibole, } \\
\text { Laumonite }\end{array}$ \\
\hline $\mathrm{A} 2(7-19)^{\mathrm{a}}$ & Quartz & & & & & $\begin{array}{l}\text { Plagioclase, } \\
\text { K-feldspar, } \\
\text { Smectite }\end{array}$ & Ilmenite, amphibole \\
\hline B21(31-41) & Quartz & & & & & $\begin{array}{l}\text { Plagioclase, } \\
\text { K-feldspar, } \\
\text { Smectite }\end{array}$ & $\begin{array}{l}\text { Ilmenite, amphibole, } \\
\text { Laumonite, stilbite-type }\end{array}$ \\
\hline B22(41-52) & & Quartz & Smectite & & & $\begin{array}{l}\text { Plagioclase, } \\
\text { K-feldspar }\end{array}$ & $\begin{array}{l}\text { Stilbite-type, amphibole, } \\
\text { Ilmenite, laumontite }\end{array}$ \\
\hline $\mathrm{C}(52-70)$ & & Smectite & & Plagioclase & Quartz & K-feldspar & \\
\hline
\end{tabular}

Mottled-Mesonatric Grey Sodosol-P7

\begin{tabular}{|c|c|c|c|c|c|c|c|}
\hline $\mathrm{A} 1(0-8)$ & Quartz & & & & & $\begin{array}{l}\text { K-feldspar, } \\
\text { Plagioclase }\end{array}$ & Smectite, halloysite, ilmenite \\
\hline $\mathrm{A} 2(8-23)^{\mathrm{a}}$ & Quartz & & & & & Smectite, & Halloysite, K-feldspar, \\
\hline B21(38-48) & Quartz & & & & $\begin{array}{l}\text { Smectite, } \\
\text { Halloysite }\end{array}$ & $\begin{array}{l}\text { Plagioclase } \\
\text { plagioclase, } \\
\text { K-feldspar }\end{array}$ & $\begin{array}{l}\text { Ilmenite, amphibole, stilbite } \\
\text { Ilmenite }\end{array}$ \\
\hline B22(48-67) & & Quartz & & Smectite & & $\begin{array}{l}\text { Halloysite, } \\
\text { Plagioclase }\end{array}$ & $\begin{array}{l}\text { K-feldspar, ilmenite, } \\
\text { Amphibole }\end{array}$ \\
\hline B3(67-78) & & & $\begin{array}{l}\text { Smectite, } \\
\text { Quartz }\end{array}$ & & Halloysite & $\begin{array}{l}\text { Plagioclase, } \\
\text { K-feldspar }\end{array}$ & $\begin{array}{l}\text { Amphibole, ilmenite, } \\
\text { Laumontite }\end{array}$ \\
\hline$C(78-150)$ & & Smectite & & & $\begin{array}{l}\text { Halloysite, } \\
\text { Quartz }\end{array}$ & $\begin{array}{l}\text { Plagioclase, } \\
\text { K-feldspar }\end{array}$ & Amphibole, ilmenite, \\
\hline \multicolumn{8}{|c|}{ Black Vertosol - P8 } \\
\hline A11(0-6) & Quartz & & & & Smectite & $\begin{array}{l}\text { Halloysite, } \\
\text { Plagioclase }\end{array}$ & $\begin{array}{l}\text { K-feldspar, clinopyroxene, } \\
\text { Ilmenite }\end{array}$ \\
\hline A12(6-19) & & Quartz & & & $\begin{array}{l}\text { Smectite, } \\
\text { Halloysite }\end{array}$ & Plagioclase, & $\begin{array}{l}\text { K-feldspar, clinopyroxene, } \\
\text { Ilmenite }\end{array}$ \\
\hline A3(19-40) & & Quartz & & Smectite & Halloysite & Plagioclase & $\begin{array}{l}\text { K-feldspar, clinopyroxene, } \\
\text { Ilmenite, laumontite }\end{array}$ \\
\hline B2(40-57) & & & Smectite & Quartz & $\begin{array}{l}\text { Halloysite } \\
\text { Plagioclase }\end{array}$ & $\begin{array}{l}\text { Clino- } \\
\text { pyroxene }\end{array}$ & K-feldspar, ilmenite \\
\hline $\mathrm{C} 1(57-66)$ & & Smectite & & Plagioclase & $\begin{array}{l}\text { Clino- } \\
\text { pyroxene }\end{array}$ & $\begin{array}{l}\text { Quartz, } \\
\text { Halloysite }\end{array}$ & K-feldspar, amphibole, \\
\hline C2(66-90) & & Smectite & & Plagioclase & $\begin{array}{l}\text { Clino- } \\
\text { pyroxene }\end{array}$ & $\begin{array}{l}\text { Halloysite, } \\
\text { Quartz }\end{array}$ & K-feldspar, ilmenite \\
\hline
\end{tabular}

${ }^{\mathrm{a}}$ The discontinuous depth interval between the A2 and B21 indicates the thick of stone-line. 
Table 7

X-Ray diffraction analysis of sand fraction of profile MN8

\begin{tabular}{|c|c|c|c|c|c|c|c|}
\hline Samples & $80 \% \quad 65-80 \%$ & $50-65 \%$ & $35-50 \%$ & $25-35 \% \quad 15$ & $15-25 \%$ & $10-15 \%$ & $5-10 \%$ \\
\hline \multicolumn{8}{|l|}{500 micron } \\
\hline A1 (0-10) & Quartz & & & & - & K-feldspar & Hematite \\
\hline A2 $(10-28)^{\mathrm{a}}$ & Quartz & & & & - & K-feldspar & Hematite \\
\hline B21(36-50) & & Quartz & & & - & Plagioclase & K-feldspar \\
\hline $\mathrm{B} 22(50-70)$ & & & Quartz & Plagioclase & - & & $\begin{array}{l}\text { inopyroxene, } \\
\text { K-feldspar }\end{array}$ \\
\hline C (70-120) & & & Plagioclase & e Quartz & - & & inopyroxene \\
\hline \multicolumn{8}{|l|}{63 micron } \\
\hline $\mathrm{A} 1(0-10)$ & Quartz & & & & - & & Plagioclase \\
\hline $\mathrm{A} 2(10-28)^{\mathrm{a}}$ & Quartz & & & & - & & Plagioclase \\
\hline B21(36-50) & Quartz & & & & - & & Plagioclase \\
\hline $\mathrm{B} 22(50-70)$ & & Quartz & & Plagioclase & - & & Smectite \\
\hline C (70-120) & & & Plagioclase & Smectite & e - & Quartz & \\
\hline
\end{tabular}

${ }^{\mathrm{a}}$ The discontinuous depth interval between the A2 and B21 indicates the thick of stone-line. 
Table 8

Distribution selected elements in soils and dolerite bedrock

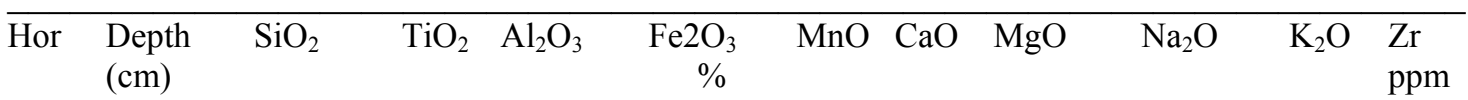

\section{Eutrophic Brown Chromosol - P5}

$\begin{array}{llllllllllll}\text { A1 } & 0-7 & 70.68 & 1.99 & 9.04 & 5.47 & 0.14 & 1.57 & 0.79 & 1.05 & 2.29 & 372 \\ \text { A3 } & 7-25^{\mathrm{a}} & 70.44 & 1.98 & 9.68 & 6.86 & 0.14 & 1.41 & 0.81 & 1.06 & 2.31 & 379 \\ \mathrm{~B} 21 & 31-50 & 54.57 & 1.02 & 18.17 & 11.50 & 0.09 & 2.04 & 1.76 & 0.82 & 1.08 & 186 \\ \mathrm{~B} 22 & 50-70 & 51.07 & 0.77 & 19.62 & 12.30 & 0.12 & 2.83 & 2.38 & 0.87 & 0.83 & 129 \\ \mathrm{~B} 3 & 70-86 & 51.81 & 0.67 & 17.83 & 11.60 & 0.13 & 5.28 & 4.27 & 1.17 & 0.82 & 107 \\ \mathrm{C} & 86-150 & 53.37 & 0.68 & 16.21 & 11.00 & 0.15 & 7.05 & 5.50 & 1.39 & 0.85 & 104\end{array}$

Mottled Subnatric Grey Sodosol-MN8

$\begin{array}{llllllllllll}\text { A1 } & 0-10 & 75.52 & 2.22 & 7.41 & 4.41 & 0.06 & 0.61 & 0.21 & 1.09 & 1.83 & 408 \\ \text { A2 } & 10-28^{\mathrm{a}} & 76.60 & 2.22 & 7.87 & 4.79 & 0.06 & 0.67 & 0.22 & 1.20 & 1.89 & 400 \\ \text { B21 } & 36-50 & 62.97 & 1.41 & 13.79 & 9.43 & 0.04 & 1.36 & 0.70 & 1.26 & 1.49 & 268 \\ \text { B22 } & 50-70 & 57.02 & 0.96 & 15.42 & 11.40 & 0.05 & 3.14 & 1.61 & 1.57 & 1.23 & 163 \\ \text { C } & 70-120 & 57.23 & 0.90 & 15.87 & 11.00 & 0.10 & 5.61 & 1.92 & 2.25 & 1.43 & 158\end{array}$

Mottled Subnatric Grey Sodosol - P4

$\begin{array}{llllllllllll}\text { A1 } & 0-7 & 75.35 & 3.10 & 7.16 & 5.04 & 0.07 & 0.68 & 0.19 & 1.05 & 1.93 & 406 \\ \text { A2 } & 7-19^{\mathrm{a}} & 67.01 & 2.54 & 8.73 & 12.45 & 0.06 & 0.64 & 0.28 & 0.94 & 1.73 & 347 \\ \text { B21 } & 31-41 & 63.78 & 2.38 & 8.59 & 16.90 & 0.05 & 0.73 & 0.32 & 0.89 & 1.61 & 306 \\ \text { B22 } & 41-52 & 61.49 & 2.16 & 11.09 & 8.47 & 0.06 & 2.21 & 0.88 & 1.31 & 1.47 & 263 \\ \text { C } & 52-70 & 57.36 & 0.79 & 15.69 & 10.85 & 0.09 & 5.18 & 2.44 & 1.83 & 1.15 & 134\end{array}$

Mottled Mesonatric Grey Sodosol - P7

\begin{tabular}{|c|c|c|c|c|c|c|c|c|c|c|c|}
\hline A1 & $0-8$ & 72.52 & 2.02 & 7.58 & 5.09 & 0.09 & 0.67 & 0.25 & 1.03 & 1.77 & 402 \\
\hline A2 & $8-23^{\mathrm{a}}$ & 68.26 & 2.00 & 8.04 & 7.46 & 0.09 & 0.68 & 0.26 & 0.95 & 1.67 & 376 \\
\hline B21 & $38-48$ & 65.44 & 1.75 & 11.14 & 12.80 & 0.04 & 0.53 & 0.38 & 0.90 & 1.40 & 313 \\
\hline B22 & $48-67$ & 74.44 & 1.62 & 9.50 & 6.41 & 0.04 & 0.78 & 0.32 & 1.20 & 1.82 & 288 \\
\hline B3 & $67-78$ & 67.25 & 1.21 & 12.39 & 9.09 & 0.04 & 1.19 & 0.63 & 1.41 & 1.46 & 207 \\
\hline $\mathrm{C}$ & $78-150$ & 58.95 & 0.95 & 15.57 & 11.20 & 0.07 & 1.82 & 0.98 & 2.10 & 1.47 & 162 \\
\hline \multicolumn{12}{|c|}{ Black Vertosol - P8 } \\
\hline A11 & $0-6$ & 59.86 & 1.45 & 11.19 & 7.86 & 0.18 & 1.69 & 1.24 & 0.47 & 1.13 & 287 \\
\hline A12 & $6-19$ & 58.12 & 1.21 & 14.08 & 9.31 & 0.25 & 2.42 & 2.24 & 0.56 & 0.90 & 229 \\
\hline A3 & $19-40$ & 57.60 & 1.20 & 15.87 & 9.84 & 0.21 & 1.89 & 1.62 & 0.48 & 0.88 & 227 \\
\hline B2 & $40-57$ & 54.40 & 0.78 & 16.60 & 10.80 & 0.17 & 4.53 & 4.00 & 0.69 & 0.63 & 130 \\
\hline $\mathrm{C} 1$ & $57-66$ & 52.24 & 0.47 & 16.83 & 10.30 & 0.16 & 7.99 & 6.26 & 0.91 & 0.43 & 64 \\
\hline $\mathrm{C} 2$ & $66-90$ & 52.18 & 0.43 & 16.34 & 9.85 & 0.15 & 9.20 & 6.77 & 1.10 & 0.45 & 58 \\
\hline \multicolumn{12}{|c|}{ Dolerite bedrock } \\
\hline \multicolumn{2}{|c|}{ Mt Nelson ${ }^{\mathrm{b}}$} & 55.52 & 0.85 & 15.58 & 11.30 & 0.17 & 2.89 & 8.51 & 2.61 & 1.37 & 132 \\
\hline \multicolumn{2}{|c|}{ Tolmans Hill ${ }^{\mathrm{c}}$} & 57.05 & 1.00 & 15.18 & 11.53 & 0.16 & 2.01 & 7.93 & 2.48 & 1.48 & 161 \\
\hline
\end{tabular}

\footnotetext{
${ }^{\mathrm{a}}$ The discontinuous depth interval between the A2 and B21 indicates the thick of stone-line.

${ }^{\mathrm{b}}$ Dolerite was sampled at $160 \mathrm{~cm}$ depth

${ }^{\mathrm{c}}$ Dolerite was sampled at $210 \mathrm{~cm}$ depth
} 
Fig 1. Simplified geological map with contours (10 $\mathrm{m}$ intervals) and soil profile locations (solid triangels). Tr (Triassic sediments); Ts (Tertiary sediments); Pm (Permian sediments); Jd (Jurassic dolerite); Q Quaternary deposits.

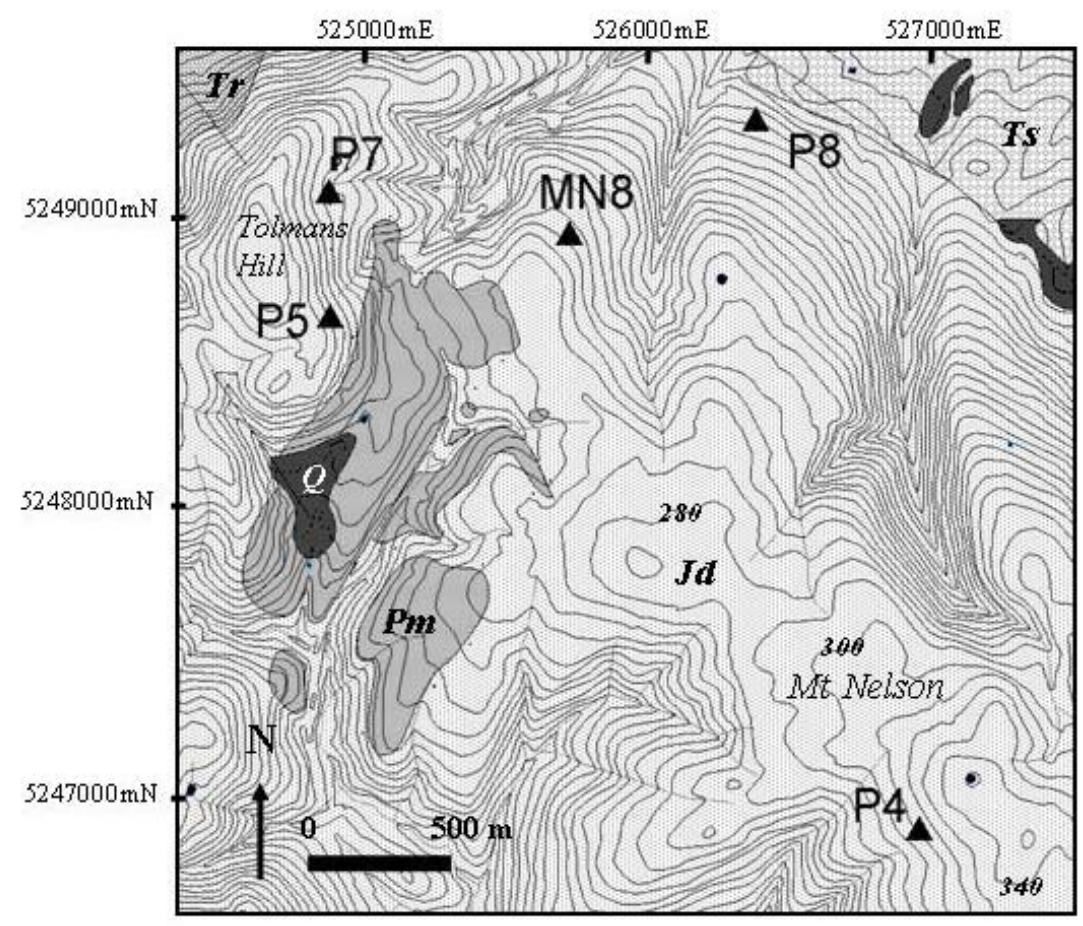


Fig 2. A proposed soil-landscape history in the southeast Tasmania

Phase 1 - Initial deep weathering of the dolerite

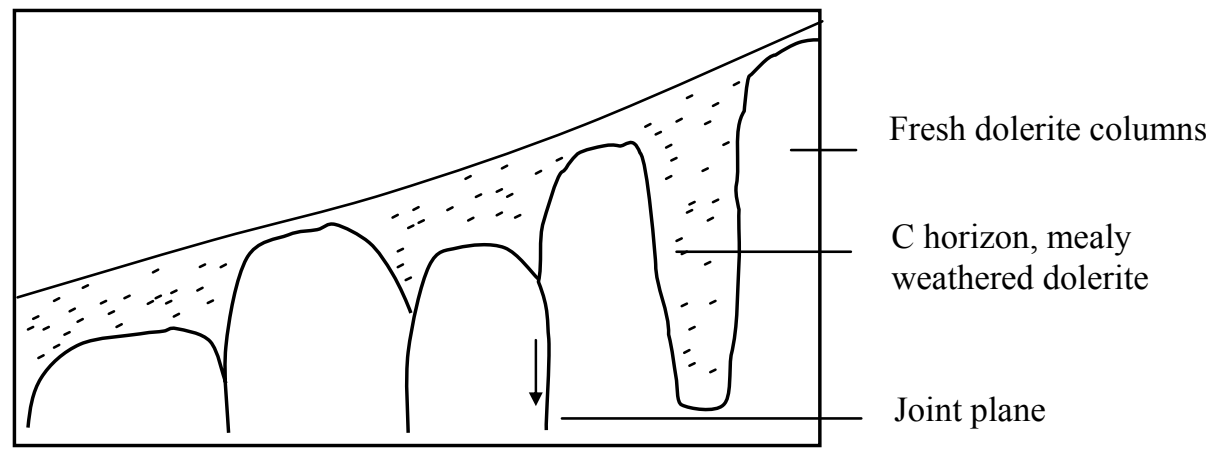

Phase 2 - Stripping

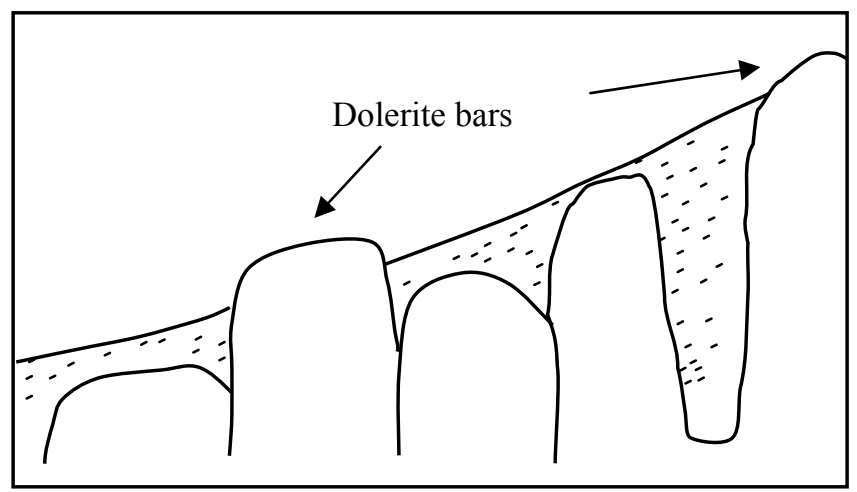

Phase 3 - Slope wash and new soil formation

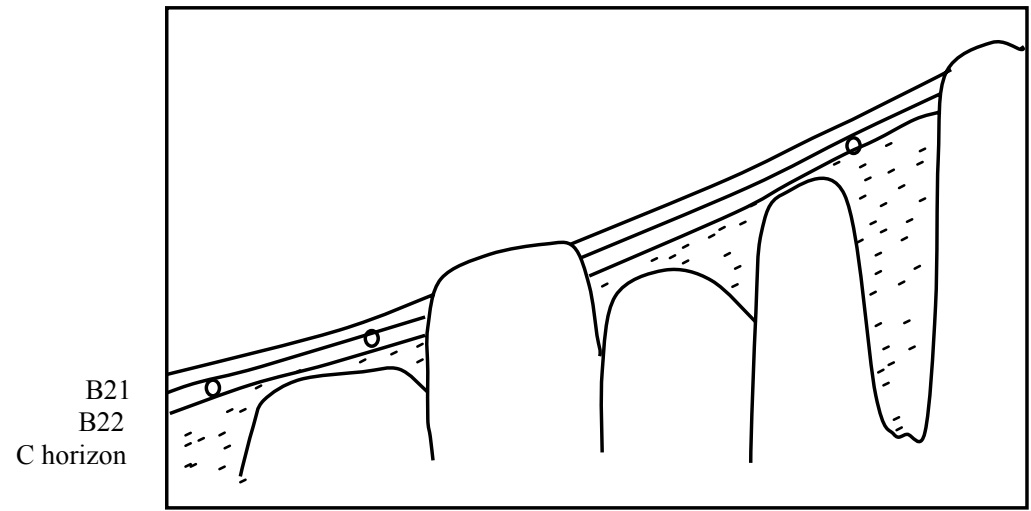


Phase 4 - formation of stone-line

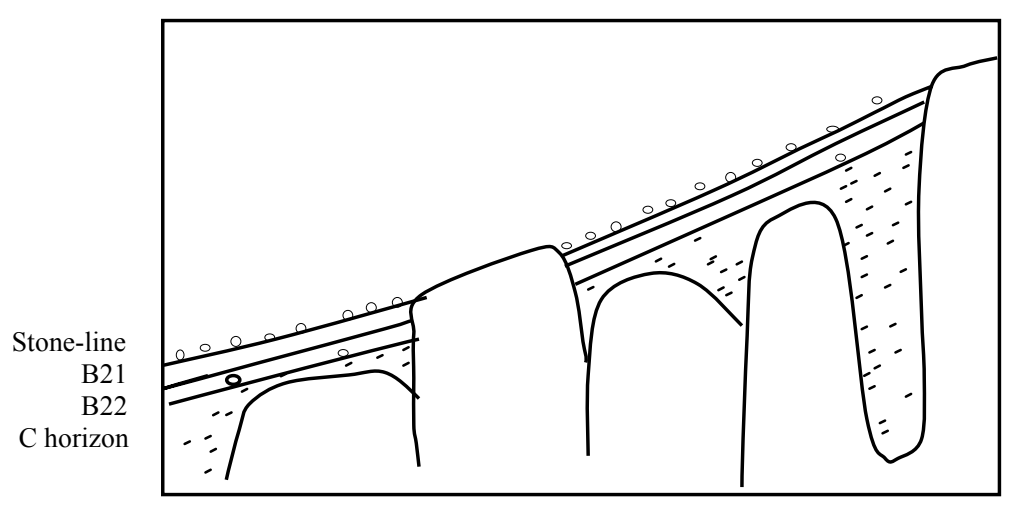

Phase 5 - Influx of fine sandy sediments

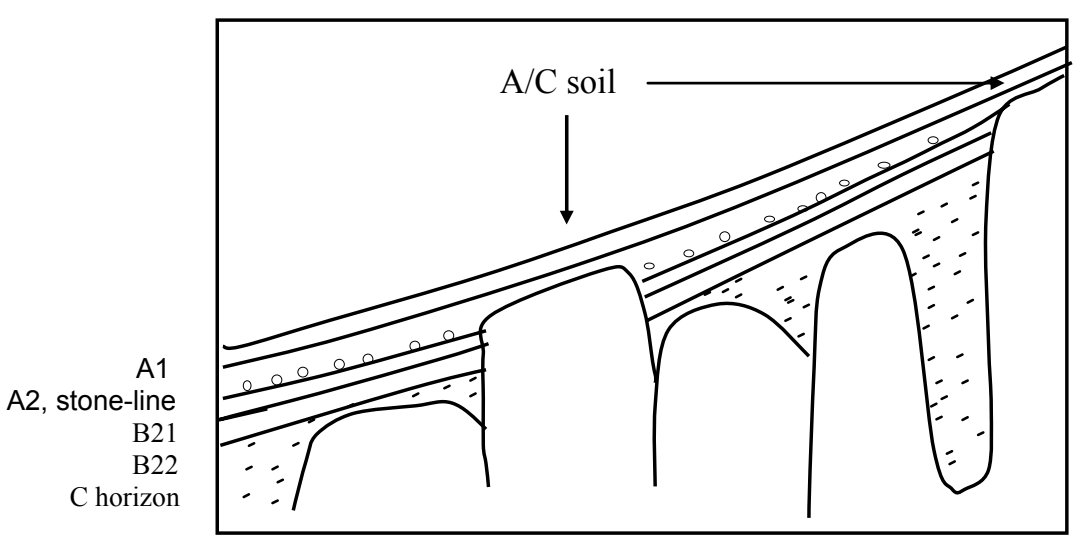

